Лариса Левицька,

Національний університет оборони України імені Івана Черняховського

ORCID ID 0000-0001-6575-9964

\title{
ОЦІНЮВАННЯ ІНФОРМАЦЙНО-КОМУНІКАЦІЙНОЇ КОМПЕТЕНТНОСТІ ЗДОБУВАЧА ВИЩОЇ ВІЙСЬКОВОЇ ОСВІТИ: ПЕДАГОГІЧНА КВАЛІМЕТРІЯ
}

Статтю присвячено виріменню актуальної педагогічної проблеми з оцінювання та вимірювання інформаційно-комунікачійної компетентності (далі - IКК) слухача (курсанта) закладу вищої військової освіти та військового навчального підрозділу закладу вищої освіти. В основу дослідження покладено застосування принципів: міждисциплінарного компетентнісного підходу в організащії освітнього процесу ЗВВО; побудови ієрархічних компетентнісних моделей здобувачів вищої військової освіти; комплексного кількісного оцінювання якості освіти на засадах педагогічної кваліметрії; дефінітивного аналізу основних понять, щуо стосуються інформатизації освітнього процесу $i$ комунікачії суб'єктів освітньої діяльності та уточнення сутності $i$ змісту цих понять щуодо особливостей їхнього застосування у педагогіці вищої військової школи.

Ключові слова: очінювання; вимірювання; інформація; комунікація; компетентність; педагогічна кваліметрія.

Постановка проблеми. Серед основних проблем вищої військової освіти проблема оцінювання та вимірювання якості підготовки військових фахівців постає як одна 3 найбільш актуальних, а впровадження в педагогіку вищої військової школи компетентнісного підходу взагалі висунули іiі в число пріоритетних. В умовах інформатизації суспільства серед низки компетентностей, якими має оволодіти слухач (курсант) закладу вищої військової освіти (далі - ЗВВО), інформаційно-комунікативна компетентність (далі - ІКК) набуває все більшого значення. Майбутній офіцер повинен швидко орієнтуватися в інформаційних потоках, аналізувати та оперативно передавати необхідну інформацію. Тому виникає потреба у розробленні відповідних підходів щодо систематизації критеріїв ІКК та їх кількісного оцінювання і вимірювання. Одним 3 таких підходів у межах освітньої діяльності ЗВВО є застосування принципів кваліметрії - галузі науки, що на сьогодні не знайшла належного застосування у педагогічній практиці вищої військової школи. Вирішенню цієї актуальної проблеми й присвячено дану статтю.

Аналіз останніх досліджень i публікацій. Загальним проблемам компетентнісного підходу у вищий освіті та формуванню окремих видів компетентностей, у тому числі - інформаційно-комунікаційної, присвячені наукові праці вітчизняних вчених-педагогів та психологів В.П.Андрущенка, I.І.Бабина, А.О.Вітченка, В.І.Лугового, О.В.Овчарука, В.І.Осьодла, B.І.Свистун, В.В.Ягупова, та ін., де розглядаються теоретичні та методологічні засади, сутнісні характеристики, функції та особливості 
реалізації компетентнісного підходу в освітньому процесі, що сприяє його вдосконаленню.

Важливою складовою в контексті даного дослідження $є$ системний аналіз педагогічних проблем, пов'язаних із здійсненням та об'єктивізацією контролю освітньої діяльності (М.А.Амоношвіллі, А.А.Вагнер, Б.Д.Ельконін, В.А.Якунін, А.Цукерман), а також комплексним оцінюванням результатів навчання здобувачів освіти, де одним із сучасних напрямів вважається застосування принципів кваліметрії - науки про вимірювання якості. Серед найбільш значущих у цій царині можна згадати роботи Г.Г.Азгальдова [4], Е.П.Райхмана, Л.В.Хведчені, В.Т.Циби та ін. Аналіз досліджень і публікацій згаданих авторів значною мірою сприятиме виробленню наукових підходів щодо оцінювання рівня сформованості інформаційно-комунікаційної компетентності здобувача вищої військової освіти та забезпечення і гарантування якості освітнього процесу в цілому.

Мета даної статті полягає в розробленні методичних рекомендацій щодо оцінювання інформаційно-комунікаційної компетентності здобувача вищої військової освіти на засадах педагогічної кваліметрії та застосуванні розроблених рекомендацій у педагогічній практиці закладів вищої військової освіти.

Методи дослідження. У дослідженні застосовуються такі теоретичні методи дослідження, як: системний аналіз і синтез, індукція та дедукція, порівняння, класифікація, узагальнення й систематизація; метод ідеалізації та абстрагування.

Виклад основного матеріалу. Освіта в Україні - це стратегічний ресурс соціально-економічного, культурного i духовного розвитку суспільства, поліпшення добробуту людей, забезпечення національних інтересів, підвищення міжнародного авторитету нашої країни, створення умов для самореалізації кожної особистості. Особливої актуальності в системі освіти у даний час набуває проблема якості, розроблення та впровадження в освітню діяльність інноваційних педагогічних концепцій i технологій, здатних конкурувати з часом, відповідати на його виклики.

У Законі України “Про вищу освіту” якість вищої освіти розглядається як рівень здобутих особою знань, умінь, навичок, інших компетентностей, що відображає іiі компетентність відповідно до стандартів вищої освіти. Ключовим поняттям у цьому визначенні $є$ компетентність - “...динамічна комбінація знань, вмінь i практичних навичок, способів мислення, професійних, світоглядних i громадянських якостей, морально-етичних цінностей, яка визначає здатність особи успішно здійснювати професійну та подальшу навчальну діяльність і $є$ результатом навчання на певному рівні вищої освіти" [1].

Чільне місце у межах інтегральної компетентності посідає одна 3 іiі складових - IКК здобувача вищої освіти. Інформаційно-комунікативна компетентність має забезпечувати спроможність особи отримувати, обробляти та усвідомлювати інформацію, що необхідна для здійснення 
соціальної діяльності (у тому числі фахової), визначати технологію формування власної діяльності та забезпечувати пї ефективність. Сформованість ІКК свідчить про уміння самостійно орієнтуватися в інформаційних потоках, зберігати та передавати інформацію за допомогою реальних об'єктів (довідники, настанови, посібники, комп'ютер, телевізор, магнітофон, телефон, радіостанція тощо) та інформаційних технологій (аудіо, відеозапис, електронна пошта, Інтернет).

Поняття інформаційно-комунікативної компетентності містить у собі дві такі категорії як “інформація” та “комунікація”.

Інформація (фран. - information - informo - надаю форму, створюю уявлення про щось, зображую) - відомості про які-небудь події, ситуації, чиюсь діяльність тощо [2, с. 314]. У соціальних системах, зокрема й освітніх, для забезпечення ефективності їх функціонування і розвитку необхідно налагодити постійний інформаційний обмін між їх елементами i підсистемами та зовнішнім середовищем. При цьому, як зазначає відомий австрійський філософ Ф.А. фон Хайєк, весь масив інформації неможливо осягнути централізованими засобами, - натомість інформація набагато ефективніше осмислюється децентралізовано [7]. Ф. Хайєк послідовно розвивав і обгрунтував тезу про принципову обмеженість людського знання, зокрема й наукового, та уперше звернув увагу на наявність у суспільстві так званої “розсіяної" інформації. Він вважає, що знання "розсіяні” серед людей, i кожен індивід має частину цих знань, що досить часто носять неформальний, інтуїтивний характер. Водночас, розсіяність інформації визначається не лише тією обставиною, що вона розпорошена між окремими членами суспільства, а й тим, що вона часто перебуває в інтуїтивній, невербалізованій формі і усвідомлюється лише у процесі конкретної діяльності (спільної чи індивідуальної) [7]. Відтак вирішальну роль у формуванні інформаційної компетентності, як складової ІКК здобувача вищої освіти, відіграє його здатність ефективно збирати і обробляти цю "розсіяну" інформацію на основі індивідуальної і колективної діяльності суб'єктів освітнього процесу.

В основу другої складової інформаційно-комунікативної компетентності покладається поняття “комунікація” (від лат. - communicatio - зв'язок, повідомлення) - спілкування, що грунтується на взаєморозумінні, повідомлення інформації від однієї людини до іншої, або кількох інших [2, с. 370]. Спілкування являє собою процес інтелектуального та емоційного обміну інформацією, в ході якого здійснюється збір, перерозподіл інформації і встановлення міжособистісних контактів.

У структурі спілкування можна виділити три взаємопов'язані сторони: комунікативну, інтерактивну i перцептивну. Комунікативна сторона спілкування, чи комунікація у вузькому сенсі слова, полягає в обміні інформацією між індивідами, що спілкуються. Інтерактивна сторона полягає в організації взаємодії між індивідами, що спілкуються, тобто в обміні не тільки знаннями, ідеями, а й діями. Перцептивна сторона спілкування 
означає процес сприйняття i пізнання один одного партнерами по спілкуванню і встановлення на цій основі взаєморозуміння. Це означає, що за допомогою мови не просто “рухається інформація”, але учасники комунікації особливим способом впливають один на одного, орієнтують один одного, переконують один одного, тобто прагнуть досягти певної зміни поведінки.

3 погляду теорії інформації при будь-якому розгляді комунікації фіксується лише формальна сторона справи, тобто - в умовах людського спілкування інформація не тільки передається, а й формується, уточнюється, розвивається. Спілкування не можна розглядати лише як відправлення інформації якоюсь системою або як прийом іiі іншою системою, оскільки, на відміну від просто “руху інформаціі” між двома пристроями, в спілкуванні двох індивідів кожен $є$ активним суб'єктом, а їх взаємне інформування припускає злагоджені дії.

Направляючи інформацію, необхідно орієнтуватися на іншого комунікатора, тобто аналізувати його цілі, мотиви і т. д., “звертатися” до нього. Тому в комунікативному процесі відбувається активний обмін інформацією. Тут особливу роль відіграє значущість інформації, оскільки люди не просто спілкуються, а й прагнуть при цьому виробити загальний зміст. Це можливо лише за умови, що інформація не просто прийнята, але зрозуміла i осмислена. Комунікативний процес - це не тільки взаємне інформування, а і спільне розуміння предмета спілкування.

Комунікативний вплив як результат обміну інформацією стає можливим лише тоді, коли “всі говорять одною мовою”, оскільки будь-який обмін інформацією можливий лише за умови, що знаки i, головне, закріплені за ними значення відомі всім учасникам комунікативного процесу. Тільки прийняття єдиної системи значень забезпечує можливість партнерів розуміти один одного.

За результатами проведеного нами дефінітивного аналізу понять “інформація" і “комунікація" та, скориставшись визначенням поняття “компетентність”, наданим у Законі України “Про вищу освіту”, можна витлумачити категорію “інформаційно-комунікативна компетентність" як таку, що об’єднує ці поняття спільною ознакою. Отже, інформаційнокомунікативна компетентність здобувача вищої освіти, на нашу думку, являє собою одну із складових інтегрального показника якості освіти як доведену особою здатність до збору необхідної інформації 3 різних джерел, іiі осмислення, аналізу, систематизації, вибору способів донесення цієї інформації до інших осіб і готовності до застосування обраних способів в ході комунікації з ними.

Головним показником рівня сформованості IКК у рамках педагогічної діяльності $\epsilon$ результати навчання як “...сукупність знань, умінь, навичок, інших компетентностей, набутих особою у процесі навчання за певною освітньо-професійною, освітньо-науковою програмою, які можна ідентифікувати, кількісно оцінити та виміряти" [1] із застосуванням принципів педагогічної кваліметрії (далі - ПК). 
Сучасна теорія ПК базується на загальному вченні про кваліметрію (лат. - quails - який, якої якості та метрія - вимірювати) - галузь науки, що вивчає методологію та проблематику комплексних кількісних оцінок якості будь-яких об'єктів: предметів, явищ або процесів [2, с. 346.]. Ї̈̈ теоретичну основу складають положення теорії вимірювання, моделювання та математичної статистики, в той час як практичне застосування лежить переважно в сфері контролю та оцінки результатів.

На сьогодні немає жодної наукової галузі і жодної царини життєдіяльності, де б не виникала потреба оцінювання та вимірювання властивостей будь-якої природи. Це стосується й гуманітарних наук, у тому числі - педагогіки, що в останні десятиріччя досить швидко математизується і стає, до певної міри, “точною" наукою. Цьому сприяє використання обчислювальної техніки, теорії програмування для побудови різних математичних моделей у найрізноманітніших сферах гуманітарного знання.

Отже, педагогічна кваліметрія визначається як дисципліна, що вивчає методологію і проблематику кількісної оцінки якості навчально-пізнавальної діяльності в цілому, педагогічних інновацій та результатів навчання, які були досягнуті здобувачами вищої освіти на певному етапі відповідно до запланованих цілей (див. Педагогічний словник 2006, 159) [3]. До того ж ПК дозволяє робити висновки про стан суб'єкта, об'єкта, процесу у будь-який момент часу і дає прогноз їхнього розвитку.

Основним процесуальним компонентом загального алгоритму застосування ПК в педагогічній практиці $є$ побудова відповідної моделі. Подібна модель щодо інформаційно-комунікативної компетентності здобувача вищої військової освіти являє собою ієрархічну структуру (від грецького "ієрархія" - розміщення частин або елементів цілого в певному порядку від найвищого до найнижчого рівнів) [2, с.293]. Представлена структура нагадує своєрідне "дерево" через зовнішню схожість 3 ним (Таблиця 1), де на відповідних ієрархічних рівнях розміщено визначені показники і критерії ІКК (критерій - від грец. крі́тү́рıо - засіб, судження одна 3 основних ознак, мірило для визначення, оцінки класифікації чогонебудь [2, с.390].

У педагогічній теорії під поняттям критерій розуміють, зазвичай, об'єктивну ознаку, за допомогою якої здійснюється порівняльна оцінка досліджуваного явища, ступеня розвитку його у різних обстежених осіб або сукупність таких якостей явища, що відображають його суттєві характеристики і саме тому підлягають оцінці. Критерії ІКК здобувача вищої військової освіти розташовано на двох ієрархічних рівнях (див.табл.1). Інтегральний показник представлено на 1-му ієрархічному рівні двома компетентностями: інформаційною та комунікативною, кожну 3 яких розгалужено на певні критерії на 2-му ієрархічному рівні (див. табл. 1).

Інтегральний показник ІКК окремого слухача, курсанта розраховується викладачем за результатами оцінювання ступеня сформованості інформаційно-комунікативної компетентності у здобувача освіти відповідно 
до розробленої системи критеріїв і оцінних шкал. Такими шкалами можуть бути або традиційна 5-и бальна, або 100 бальна - в європейській кредитнотрансферній накопичувальній системі ЄКТС. Якщо, наприклад, шкала п'ятибальна, то оцінний показник компетентності здобувача освіти за певним критерієм співвідноситься 3 еталоном - бал “5” - як найвищий прояв доведеної здатності слухача (курсанта) до застосування цього критерію у практичній діяльності. При цьому, з урахуванням особливостей формування ІКК, найбільш доцільним, 3 дидактичної точки зору, $\epsilon$ використання інтерактивних технологій.

Далі, результати оцінювання по кожному з критеріїв $K_{i}$ (де $i$ - № № критеріїв, у даному випадку - від № 1.1 до № 2.7), співвідносяться з балом “5” - еталонним проявом будь-якого критерію за формулою:

$$
K_{i j}=\frac{P_{i j}}{P_{j}^{e m}},
$$

де: $K_{i j}$ - відносний показник прояву і-го критерію за результатами оцінювання ј-го здобувача $0 \leq K_{i j} \geq 1$,

$P_{i j}$ - абсолютний показник прояву і-го критерію при оцінюванні ј-го респондента) - від балу “2” до балу “5”;

$P_{i}^{e m}-$ еталонний показник прояву і-го критерію - (бал “5”).

При цьому, прояв критерію, оцінений балом “2” прирівнюється до “0”. Наприклад, якщо критерій № 1.2 (див. Табл.1) - “Здатність осмислювати та систематизувати інформацію" оцінено викладачем у 3 бали, то відносний показник $K_{1.2}=3,0: 5=0,6$. А якщо, припустимо, критерій №2.6 (див. Табл.1) "Здатність ефективно спілкуватися в умовах дефіциту часу, небезпеки, суперечливості обстановки" оцінено у 2,0 бали, то $-K_{2.6}=0: 5=0$. Аналогічно визначається прояв усіх інших критеріїв.

Структура інформаційно-комунікативної компетенції Таблиця 1

\begin{tabular}{|c|c|c|c|}
\hline $\begin{array}{l}\text { Інтегральний } \\
\text { показник }\end{array}$ & $\begin{array}{l}\text { Критерії 1-го } \\
\text { рівня 1єрархії }\end{array}$ & Критерії 2-го рівня ієрархії & $\begin{array}{l}\text { Koефi- } \\
\text { цієнти } \\
\text { вагомості } \\
\text { Mi }\end{array}$ \\
\hline \multirow{4}{*}{$\begin{array}{l}\text { Інформаційно- } \\
\text { комунікативна } \\
\text { компетентність }\end{array}$} & \multirow[t]{2}{*}{$\begin{array}{l}\text { 1.Інформаційна } \\
\text { компетентність }\end{array}$} & $\begin{array}{l}\text { 1.1.Здатність збирати та обробляти } \\
\text { інформацію } 3 \text { різних } \\
\text { орієнтуватися в інформаційних потоках, } \\
\text { у тому числі - у військової сфері }\end{array}$ & 0,1 \\
\hline & & $\begin{array}{l}\text { 1.2.3датність } \quad \text { осмислювати } \\
\text { систематизувати інформацію }\end{array}$ & 0,1 \\
\hline & \multirow[t]{2}{*}{$\begin{array}{l}\text { 2.Комунікативна } \\
\text { компетентність }\end{array}$} & $\begin{array}{l}\text { 2.1.Здатність володіти "професійною } \\
\text { мовою”, “комунікативно-мовленнєвою } \\
\text { стратегією" та “комунікативно- } \\
\text { мовленнєвою тактикою" }\end{array}$ & 0,15 \\
\hline & & 2.2.3датність & 0,15 \\
\hline
\end{tabular}




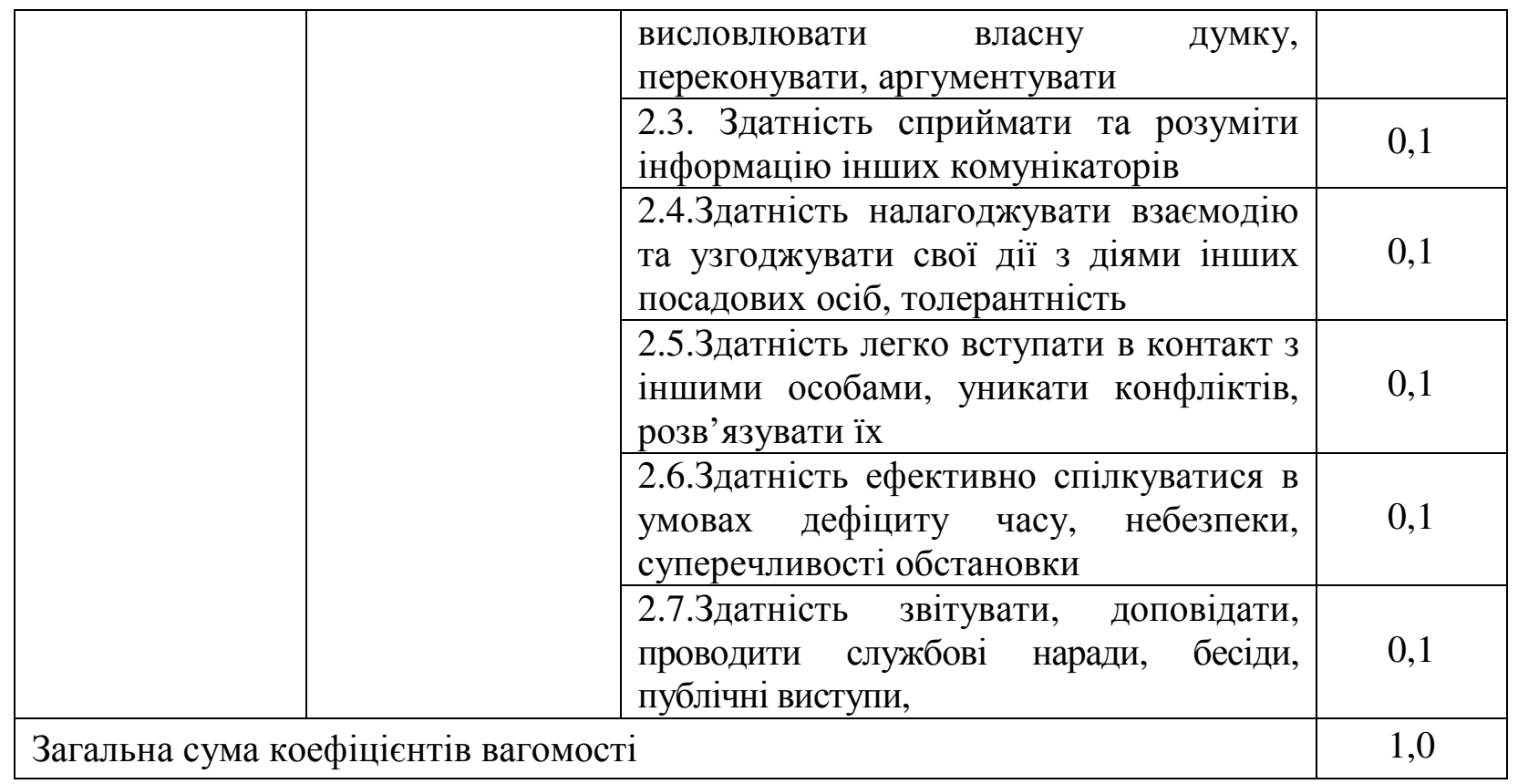

Значущість наведених критеріїв, з точки зору їх впливу на інтегральний показник ІКК $\epsilon$ різною, тому кожному 3 них призначається відповідний коефіцієнт вагомості. Коефіцієнти вагомості доцільно призначати методом експертних оцінок, що знайшло своє практичне використання в педагогічній кваліметрії.

Коефіцієнт вагомості $M_{\Sigma}$ інтегрального показника ІКК $-K_{\Sigma}$ дорівнює "1" або 100 \%. Експерту потрібно розподілити ці 100\% між усіма критеріями, призначивши кожному 3 них відповідну частку від 100\% 3 урахуванням їх ваги у межах коефіцієнта вагомості $M_{\Sigma}$ і внести ці дані у відповідну індивідуальну анкету. Дані 3 індивідуальних анкет за результатами опитування $n$ експертів вносяться ведучим експертного опитування в узагальнену анкету для підрахунку усереднених коефіцієнтів вагомості $M_{j_{c p}}$ у \% та у відносних показниках.

$M_{j_{c p}}$ визначається за формулою
де: $M_{j_{c p}}=\frac{\sum_{i=1}^{n} M_{i}}{n}$,

$$
\sum_{i=1}^{n} M_{i}-\text { сумарний поке }
$$

Узагальнені результати у відносних показниках заносяться у відповідну колонку таблиці. Варіант результатів експертного опитування представлено у колонці “Коефіцієнти вагомості Мі” (див. Табл. 1). 
Далі розраховується інтегральний показник сформованості ІКК ј-го

здобувача за формулою (3) :

$$
K_{\sum j}=\sum_{i=1}^{m} K_{i j} \times M_{j},(\%)
$$

де: $K_{\sum j}-$ рівень сформованої інтегральної інформаційнокомунікаційної компетентності $j$-го слухача (курсанта);

$m$ - кількість критеріїв 2-го рівня ієрархії;

$K_{i j}$

- оцінка $j$-го слухача (курсанта) за $i$-м критерієм;

$M_{i}$ - коефіцієнт вагомості $i$-го критерію.

Тепер інтегральний показник сформованості ІКК $j$-го слухача визначатиметься як сума добутків $K_{i}$ х $M_{i}$, Наприклад:

$\mathrm{K}_{1.1}=\mathrm{K}_{1.1} \times \mathrm{M}_{1.1}=0,6 \times 0,1=0,06$;

$\mathrm{K}_{1.2}=\mathrm{K}_{1.2} \times \mathrm{M}_{1.2}=0,8 \times 0,1=0,08$

$\mathrm{Kj}_{2.1}=\mathrm{K}_{2.1} \cdot \times \mathrm{M}_{2.1}=0,8 \times 0,1=0,08$;

$\mathrm{Kj}_{2.2}=\mathrm{K}_{2.2} \cdot \times \mathrm{M}_{2.2}=1,0 \times 0,15=0,15$;

$\mathrm{Kj}_{2.3}=\mathrm{K}_{2.3} \cdot \times \mathrm{M}_{2.3}=0,6 \times 0,15=0,09$;

$\mathrm{Kj}_{2.4}=\mathrm{K}_{2.4} \times \mathrm{M}_{2.4}=0,8 \times 0,1=0,08$;

$\mathrm{Kj}_{2.5}=\mathrm{K}_{2.5} \times \mathrm{M}_{2.5}=0,0 \times 0,1=0,0$

$\mathrm{K}_{2.6}=\mathrm{K}_{2.6} \times \mathrm{M}_{2.6}=0,8 \times 0,1=0,08$;

$\mathrm{Kj}_{2.7}=\mathrm{K}_{2.7} \times \mathrm{M}_{2.7}=0,6 \times 0,1=0,06$;

Тоді, інтегральний показник $-\sum \mathbf{K}_{\mathbf{J}} \mathbf{= 0 , 6 8}$ або $68 \%$ від еталону $-100 \%$.

Втрати склали $32 \%$, що з використанням наведеної методики дозволяє визначити розподіл втрат за окремими показниками, а відтак, отримати об'єктивну картину для аналізу результатів навчання та управління якістю підготовки кожного здобувача вищої військової освіти.

Висновки та перспективи подальших досліджень. Проблема кількісної оцінки якості основних компонентів освітнього процесу $€$ перманентно актуальною. Вона розглядається в контексті розвитку всієї педагогічної системи, приймаючи форми, адекватні гносеології наукового пізнання та цілям освіти. Однією з важливих цілей вищої військової освіти $€$ формування інформаційно-комунікаційної компетентності слухачів (курсантів), як доведеної здатності до відбору з різних джерел необхідної інформації, ii аналізу та систематизації i вибору способів доведення (донесення) зазначеної інформації іншим особам (особі) в ході комунікації.

Сформованість цієї компетентності свідчить про уміння самостійно орієнтуватися в інформаційних потоках, зберігати та передавати інформацію за допомогою реальних об'єктів (довідники, настанови, посібники, комп'ютер, телевізор, магнітофон, телефон тощо) та інформаційних технологій (аудіо, відеозапис, електронна пошта, Інтернет).

В умовах глобальної інформатизації суспільства інформаційнокомунікативна компетентність набуває все більшого значення i в межах управління якістю освітньої діяльності потребує інноваційних підходів до іiі 
кількісного оцінювання. Одним 3 таких підходів є впровадження в освітній процес педагогічної кваліметрії, яка вивчає методологію і проблематику кількісної оцінки якості навчальних технологій та освітньої діяльності в цілому. Подібний підхід дає змогу цілеспрямовано управляти освітньою діяльністю і досягати визначених результатів навчання, що має стати предметом подальших досліджень.

\section{ЛІТЕРАТУРА}

1. Про вищу освіту: Закон України від 1 липня 2014 року № 1556-VII (Відомості Верховної Ради (ВВР), 2014, № 37-38, ст.2004).

2. Сучасний словник іншомовних слів. - К.: Довіра, 2006. - 789 с. - (Словник України).

3. Педагогический словарь / В. Н. Наумчик и др. - Мн., 2006. -159 с.

4. Азгальдов, Г. Г., Райхман, Э. П. О квалиметрии. - М.: Издательство стандартов, 1972. $-172 \mathrm{c}$.

5. Моніторинг якості підготовки військових фахівців у вищих військових навчальних закладах та військових навчальних підрозділах вищих навчальних закладів Збройних Сил України: наук.-метод посіб. /А. М. Зельницький, О. А. Заболотний, Ю. І. Приходько та ін.; за заг. ред. І. В. Толока.: - ХНУПС, 2017, - с. 120.

6. Концептуальні засади гарантування якості підготовки майбутніх офіцерів Збройних сил України у вищих військових навчальних закладах. Вісник Черкаського університету. Серія пед. науки. - Ч., 2017. - № 6. - С. 71-83.

7. Национальная инновационная система: теоретическая концепция. Рассеянное знание [Електронний ресурс]. - Режим доступу: http://www.schumpeter.ru/article.php?id=6\&book=concept.

\section{REFERENCES}

1. Pro vyshy osvity: Zakon Ykrainu [The law of Ukraine on Higher education] 1.07.2014 № 1556-VII.(Vidomosti Verkhovnoi Rady (VVR), 2014, № 37-38, 2004.

2. Suchasnyi slovnyk inshomovnykh sliv [Modern Dictionary of Foreign Languages], (2006). (in Ukrainian).

3. Pedahohycheskyi slovar [Pedagogical dictionary], (2006). (in Russian).

4. Azghaldov, H.H., Raikhman, E.P. (1972). O kvalymetryy [About qualimetry], Moscow, Izdatelstvo standartov, (in Russian).

5. Zelnytskyi, A.M., Zabolotnyi, O.A., Prykhodko, Yu.I. (2017). Monitorynh yakosti pidhotovky viiskovykh fakhivtsiv u vyshchykh viiskovykh navchalnykh zakladakh ta viiskovykh navchalnykh pidrozdilakh vyshchykh navchalnykh zakladiv Zbroinykh Syl Ukrainy [Monitoring of Training Quality of Military Specialists in Higher Military Educational Establishments and Military Educational Units of Higher Educational Institutions of the Armed Forces of Ukraine] Kharkiv: KhNUPS, 120 (in Ukrainian).

6. Kontseptual'ni zasady harantuvannya yakosti pidhotovky maybutnykh ofitseriv Zbroynykh syl Ukrainy u vyshcykh viys`kovykh navchal'nykh zakladah. [Conceptual principles of the guarantee quality of preparation future officers armed forces of Ukraine in higher education institutions] Visnuk Cherkas`kogo universitety. Seriya ped, nauki. - Ch. (2017). № 6. $71-83$.

7. National innovation system: theoretical concept. Scattered knowledge [Electronic resource] - Access mode: http://www.schumpeter.ru/article.php?id=6\&book=concept.

\section{PEЗЮME}




\title{
Оценивание информационно-коммуникационной компетентности соискателя высшего военного образования: педагогическая квалиметрия
}

Статья посвящена решению актуальной педагогической проблемы по оцениванию $и$ измерению информационно-коммуникационной компетентности соискателя высшего военного образования. В основу исследования положено использование приниипов: междисииплинарного компетентностного подхода в организации образовательного процесса: разработки иерархических компетентностных моделей выпускника высшего военного учебного заведения; комплексного количественного оченивания качества образования с использованием педагогической квалиметрии; дефинитивного анализа основных понятий, которые относятся к информатизации образовательного процесса $и$ коммуникации субъектов образовательной деятельности, уточнения сути и содержания этих понятий относительно особенностей их использования в педагогике высшей военной школьл.

Ключевые слова: оценивание; измерение; информация; коммуникация; компетентность; педагогическая квалиметрия.

\section{SUMMARY}

\author{
Larisa Levickaja \\ National Defence University of Ukraine \\ named after Ivan Cherniakhovskyi
}

\section{Evaluation of information and communication competence of the applicant for higher military education: pedagogical qualimetry}

Introduction. The article is devoted to the topical pedagogical issue solving on evaluating and measuring the information and communication competence (ICC) of the applicant for higher military education based on hierarchical modeling and application of the pedagogical qualimetry principles. The basis for the research is the scientific approaches concerning the sequential differentiation of the integral indicator of the ICC to the level of criteria, the manifestation of which one can quantify and measure in the process of pedagogical practice in higher military education institutions.

Purpose is development and implementation of the technique of quantitative evaluation of information and communication competence of the applicant for higher military education with the application of the pedagogical qualimetry basic principles.

Methods. The following theoretical methods used in the research: system analysis and synthesis, induction and deduction, comparison, classification, generalization and systematization; idealization and abstraction.

Results. The method of quantitative evaluation of information and communication competence of the applicant for higher military education with the application of the basic principles of pedagogical qualimetry, which can be implemented into the educational process of institutions of higher military education, is developed.

Originality. The hierarchical model of information and communication competence of the applicant for higher military education was developed, and the basic principles of pedagogical qualimetry for the complex quantitative evaluation of the mentioned competence were applied.

Conclusion. The article deals with the issue concerning evaluation of the information and communication competence of the applicant for higher military education. The mentioned above competence is proved to be an applicant's ability to select necessary information from various sources, to analyze and systematize it and choose the methods of reporting the mentioned information to other persons (person) during communication.

Keywords: estimation"; measurement; information; communication; competence; pedagogical qualimetry. 